\title{
Deneysel Diyabetik Nefropatide Patomorfoloji ve Apoptozis
}

\author{
Nihat YUMUŞAK ${ }^{1, a, *}$ \\ ${ }^{1}$ Harran Üniversitesi, Veteriner Fakültesi, Patoloji Anabilim Dalı, Şanlıurfa, Türkiye. \\ aORCID: 0000-0002-9299-2902
}

\begin{abstract}
Geliș Tarihi: Geliș Tarihi: 08.02.2020
Kabul Tarihi: 05.06.2020

Özet: Bu çalışmada diyabetik nefropatiye bağlı oluşan böbrek hasarında histopatolojik ve apoptotik bulguların değerlendirilmesi amaçlandı. Çalışmada 16 rat rastgele olarak kontrol $(n=8)$ ve üç gün arayla iki kez streptozisinle $(60 \mathrm{mg} / \mathrm{kg}$, i.p) uyarılmış diyabet $(n=8)$ olmak üzere iki gruba ayrıldılar. Son uygulamayı takip eden 90. günde ratlar uyutularak böbrekleri patolojik incelemeler amacıyla alındı. Dokulara histopatolojik olarak hematoksilen-eozin ve immunohistokimyasal olarak kaspas-3, kaspas-8, kaspas-9 ve TUNEL işaretlemeleri yapıldı. Histopatolojik olarak, tubullerde dilatasyon, atrofi, dejenerasyon, nekroz, glomeruluslarda ise hipertrofi ve vasküler değişikler görüldü. İntersitisyel alanlarda ise yer yer peritubuler, perivasküler ve periglomeruler fibrozis ve inflamasyonlar gözlendi. İmmunohistokimyasal olarak, kaspas-3'ün birçok tubulde pozitif olduğu ayrıca glomerullerde ve intersitisyumda tek tük pozitif hücre ile karşılaşıldı. Kaspas-8 ve kaspas-9 antikorlarının ise birçok tubulde reaktif oldukları belirlendi. TUNEL boyamalarında ise yaygın pozitiflik tubulerde, yer yer intersitisyumda ve glomeruluslarda belirlenmiştir. Sonuç olarak, diyabete bağlı oluşan nefropatide bütün böbrek dokusunda hasarın şekillendiği belirlenmiştir.
\end{abstract}

Anahtar Kelimeler: Diyabetik nefropati, Patomorfoloji, Apoptozis.

\section{Pathomorphology and Apoptosis in Experimental Diabetic Nephropathy}

\begin{abstract}
The aim of this study was evaluated by histopathological and apoptical of kidney damage in rats with streptozotocin induced diabetes. Sixteen rats were randomly divided into two groups as a control group $(n=8)$ and rats with twice dose (streptozotocin, $60 \mathrm{mg} / \mathrm{kg}$, i.p.) of the diabetic group. At the end of the last given of streptozotocin 90 . days, the rats were sacrificed and the kidneys were removed for histopathological and immunohistochemical examination. For histological analysis tissue sections were stained with hematoxylin-eosin, for the immunohistochemical studies sections were stained with caspase-3, caspase-8, caspase-9 and TUNEL assay method. Histopathologically, the kidney in the diabetic group showed glomerular sclerosis, thickening, and membrane hyalinization, tubular atrophy, tubular dilatation, cellular vacuolization, and reabsorption droplets in tubule lumens. In the interstitium inflammation, and fibrosis also were seen. Immunohistochemically, increased caspase-3 immunoreactivity in the tubular epithelial cells and few glomerular and interstitial cells. Caspase- 8 and caspase- 9 were reactive in tubules. In general, diffuse immunoreactivity in tubules, glomerules and interstitium were observed in TUNEL staining. These results indicate that all component in the kidneys of diabetic rats were damaged.
\end{abstract}

Keywords: Diabetic nephropathy, Patomorphology, Apoptosis.

\section{Giriş}

Diyabetes mellitus (DM), yeterli insülin salgılanamaması veya salgılanan insülinin etkisiz kalması sonucu oluşan, hiperglisemi ile seyreden karbonhidrat, yağ ve protein metobolizmasında bozulmalara neden olan kronik seyirli bir hastalıktır (Jones ve ark., 2013; Njolstad ve ark., 2003; Strippoli ve ark., 2003). Dünya Sağlık Teşkilatı (2006) verilerine göre gün geçtikçe gerek ülkemizde gerekse dünyada DM insidensinde artışın olduğu görülmektedir. DM doğrudan birçok klinik semptoma neden olurken hastalığa bağlı oluşan komplikasyonlar ciddi mortalite ve morbiditeye sebep olmaktadır. Hastalarda retinopati, dermatitis, nöral, kardivasküler ve böbrek bozuklukları en yaygın görülen komplikasyonlardır (Krolewski ve ark., 1996; Nadir ve ark., 2003). Diyabetli hastaların \%44'ünde görülen ve klinik bir bulgu olarak kabul edilen diyabetik nefropatinin (DN) ilk evrelerinde belirgin bir bulgunun görülmemesi çoğu hasta tarafından göz ardı edilir. Böbrek fonksiyonlarına ait klinik semptomların başladığı ve histopatolojik hasarın şekillendiği kronik dönem ise son dönem böbrek yetersizliği olarak tanımlanır ve hasta dialize bağlımlı olur. Bu nedenle DM hastalarında yüksek tedavi giderlerine ve mortalite neden olmaktadır (Fiorina ve ark., 2005; Jones ve ark., 2013; Parving ve ark., 1996).

DN oluşumunda birçok faktör rol alırken, genetik bozukluk, yüksek glikoz düzeyi, reninangiotensin sistem, glomeruler hiperfiltrasyon ve serbest oksijen radikalleri önemli etmenler arasında yer alır (Friedman, 1996). DM'sa bağlı oluşan hiperglisemi ve glukoz toksikasyonu da başlıca nefropatnin patogenzinde rol alır. Kronik 
hiperglisemi arteriyel endotelde yangısal medyatörlerin ve nitrik oksit salınımının artırılmasına neden olarak glomerulosklerozisin oluşumuna sebep olur (Krolewski ve ark., 1996; Van Dijk ve Beri, 2004). Bununla birlikte tek başına hiperglisemi nefropatinin oluşumu için yeterli değildir. Glukoz birikimi de benzer reaksiyonlara neden olurken artan glukoz hücrelerde proliferasyonlara, hücre dışı matriksin ve TGF- $\beta$ 'nın artışına neden olarak hücreleri etkiler. Aşırı glukoz hücrelerde nikotinamid adenin dinükleotid fosfat (NADPH) gibi antioksidandtların azalmasına bu da dokuda serbest radikallerin artışına neden olur (Nadir ve ark., 2003; Van Dijk ve Beri, 2004; Wang ve Chahners, 1993). Artan serbest oksijen radikalleri ise damar endotelinde hasarın şekillenmesine neden olur. Sonuçta hücrede $\mathrm{Na}+\mathrm{K}+\mathrm{ATP}$ az aktivitesi azalarak hücre içinde sodyum birikir. Buna bağlı olarak hücrede ödem ve fonksiyon bozukluğu şekillenir. Bu değişiklikler dokularda inflamasyona ve nekroza neden olurken hücrelerde apoptozisi tetikler (Duran-Salgado ve Rubio-Guerra, 2014). DN'de akut dönemdeki histopatolojik bulgular hastalığın tanısında belirleyici değildir. Patognomik histolojik bulgular daha çok kronik dönemde özellikle vasküler yapınında bozulması ile birlikte oluşur (Estacio ve ark., 2000; Fioretto ve ark., 2000). Histopatolojik bulgular daha çok glomeruler yapıda şekillenmesine rağmen, intersitisyel, tubuler ve vasküler yapınında etkilendiği bildirilmektedir (Mauer ve ark., 1990; Phillips ve Steadman, 2002; Wolf, 2004).

$\mathrm{Bu}$ çalışma ile, diyabetik nefropatide görülen patolomorfolojik değişikliklerin ve apoptozisin belirlenmesi amaçlandı.

\section{Materyal ve Metot}

\section{Deney protokolü}

Çalışmada 200-250 g ağırlıklarında ve 5-6 haftalık yaşlarda 16 Wistar albino türü erkek rat kullanıldı. Çalışmadan bir hafta önce ratların laboratuvar koşullarına uyumu sağlandı. Hayvanlar

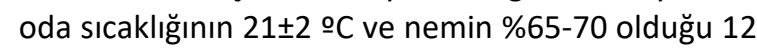
saat aydınlık/karanlık siklusların sağlandığı ortamda polypropilen kafeslerde tutuldu. Standart serbest yemleme ve su ile beslendi. Yapılan deneysel çalışmalar deney hayvanları ünitesinde deney hayvanları etik kurul onayı ve gözetimi altında yapıldı (Onay No: 2017/03).

Çalışma öncesi ratlar rastgele olarak; herhangi bir işlem uygulanmayan Grup I (Kontrol grubu $(n=8)$ ) ve 3 gün aralıklarla iki kez intraperitonel olarak streptozotocin (STZ, $60 \mathrm{mg} / \mathrm{kg}$, Sigma, MO, USA; $0.05 \mathrm{M}$ citrate buffer; $\mathrm{pH} 4.5$ ) uygulanan Grup II (diyabetik grup $(n=8)$ ) olmak üzere ikiye ayrıldılar. STZ uygulamayı takip eden 48. saatlerde kan glukoz ölçümü (GlucoDr SuperSensor ${ }^{\mathrm{TM}}$ Blood Glucose Monitoring System, AGM-2200, All Medicus Co., Ltd., Republic of Korea) yapıldı. Ölçümlerde 16.7 $\mathrm{mmol} / \mathrm{L}$ tespit edilen ratlar diyabetik olarak kabul edildi. Son STZ uygulamasını takip eden 90. günde ratlar uyutuldu ardından uygun yöntemlerle böbrek dokuları alınarak histopatolojik ve immunohistokimyasal incelemeler amacıyla \%10 tamponlu nötral formalinde tespit edildi.

\section{Histopatolojik çalışmalar}

Tespit edilen doku örneklerinden formalini uzaklaştırmak amacıyla dokular akarsuda bir gece yıkandı. Ardında rutin patolojik doku takibine alınarak dereceli alkol (\%50, \%75, \%96, \%100) ve ksilol serilerinden geçirilerek parafinde bloklandı. Hazırlanan bloklardan $5 \mu$ kalınlığında kesitler Leica RM 2125 RT ile ilk üç kesit ve her onuncu kesitler lamlara alındı. Hazırlanan preparatlar alkol ve ksilol serilerinden geçirilerek hematoksilen eozin (HE) boyaması ile boyandı. Tüm örnekler yüksek çözünürlüklü ışık mikroskobunda (Olympus DP-73 camera, Olympus BX53-DIC microscope; Tokyo, Japan) X40-X100-objektif büyütmelerinde incelendi.

\section{İmmunohistokimyasal çalışmalar}

İmmunohistokimyasal boyamalar primer antikorların protokolü doğrultusunda streptavidinbiotin-peroksidaz (ABC) yöntemiyle yapıldı. Bu amaçla daha önce hazırlanan parafin bloklardan $5 \mu$ kalınlığında kesitler lysinli lama alınarak alkol ve ksilol ile deparafinize ve dehidre edildi. Dokulardaki antijenin geri kazanımı için kesitler mikrodalga fırında 700W'da 20 dakika ph 6.0 Sitrate buffer ile muamele edildi. Ardından peroksidaz aktivitesini baskılamak amacıyla 15 dakika oda sıcaklığında $\% 0.3 \mathrm{H}_{2} \mathrm{O}_{2}$ 'de nemli kamarada bekletildi. Primer antikordan önce 20 dakika oda sıcaklığında \%5'lik normal keçi serumunda protein baskılaması yapıldı. Daha sonra kesitler Caspase-3 (1:200, Invitrogen, PA5-16335), Caspase-8 (1:50, Abcam, ab4052) and Caspase-9 (1:100, Abcam, ab52298) primer antikoru damlatılarak 1 saat oda sıcaklığında bekletildi. PBS (Phosphate buffered saline) ile yıkanan kesitler 30 dakika sekonder antikorda bekletildikten sonra reaksiyonun görünürlüğünü sağlamak amacıyla kromojen olarak diaminobenzidine (DAB, Lab Vision)'de 3 dakika bekletildi. Zemin boyaması için ise Harris Hematoksilen kullanıldı. Son olarak alkol ve ksilolden geçirilen kesitler entellan ile kapatıldı.

\section{TUNEL boyama}

TUNEL (Terminal Deoxynucleotidyl Transferasemediated Deoxyuridine Triphosphate Nick end Labeling) işaretlemeleri üretici firma katalog prosedürüne (In Situ Cell Death Detection Kit, POD, Roche, Germany) göre yapıldı. Bu amaçla 
parafin bloklardan $5 \mu$ kalınlığında kesitler lysinli lama alındı, alkol ve ksilol ile deparafinize ve dehidre edildi. Ardından peroksidaz aktivitesini baskılamak amacıyla kesitler 15 dakika oda sıcaklığında \% $0.3 \mathrm{H}_{2} \mathrm{O}_{2}$ 'de bekletildi. PBS ile yıkanan kesitler Protein K $(20 \mathrm{mg} / \mathrm{ml}$; Roche, Mannheim, Germany) ile oda sıcaklığında ve nemli kamarada 15 dakika muamele edildi. Yıkanan kesitler daha sonra taze hazırlanan $50 \mu$ l of TUNEL reaction mixture (TdT \& dUTP) solüsyonunda karanlık ortamda $37{ }^{\circ} \mathrm{C}^{\prime}$ de 1 saat bekletildi. Ardından kesitler $50 \mu \mathrm{l}$ antifluorecein antikor konjugat POD enzim homojenatıyla kaplanarak 30 dakika $37{ }^{\circ} C^{\prime}$ de bekletildi. Son olarak yıkanan kesitler AEC (3-Amino
9-Ethyl Carbasole, Dako, Glostrup, Denmark) ile 10 dakika muamele edildikten sonra hematoksilen ile zemin boyaması yapılarak lamelle kapatıldı.

\section{Bulgular}

\section{Histopatolojik bulgular}

Histopatolojik olarak glomeruluslar, tubuluslar, intersitisyum ve damarlarda görülen patolojik parametreler değerlendirildi. Kontrol grubuna ait böbreklerde herhangi bir patolojik lezyonla karşılaşılmadı. Buna karşın, diyabetik ratlara ait böbreklerde belirgin hasarın şekilendiği görüldü (Şekil 1). Glomeruluslardaki kapillalarda belirgin
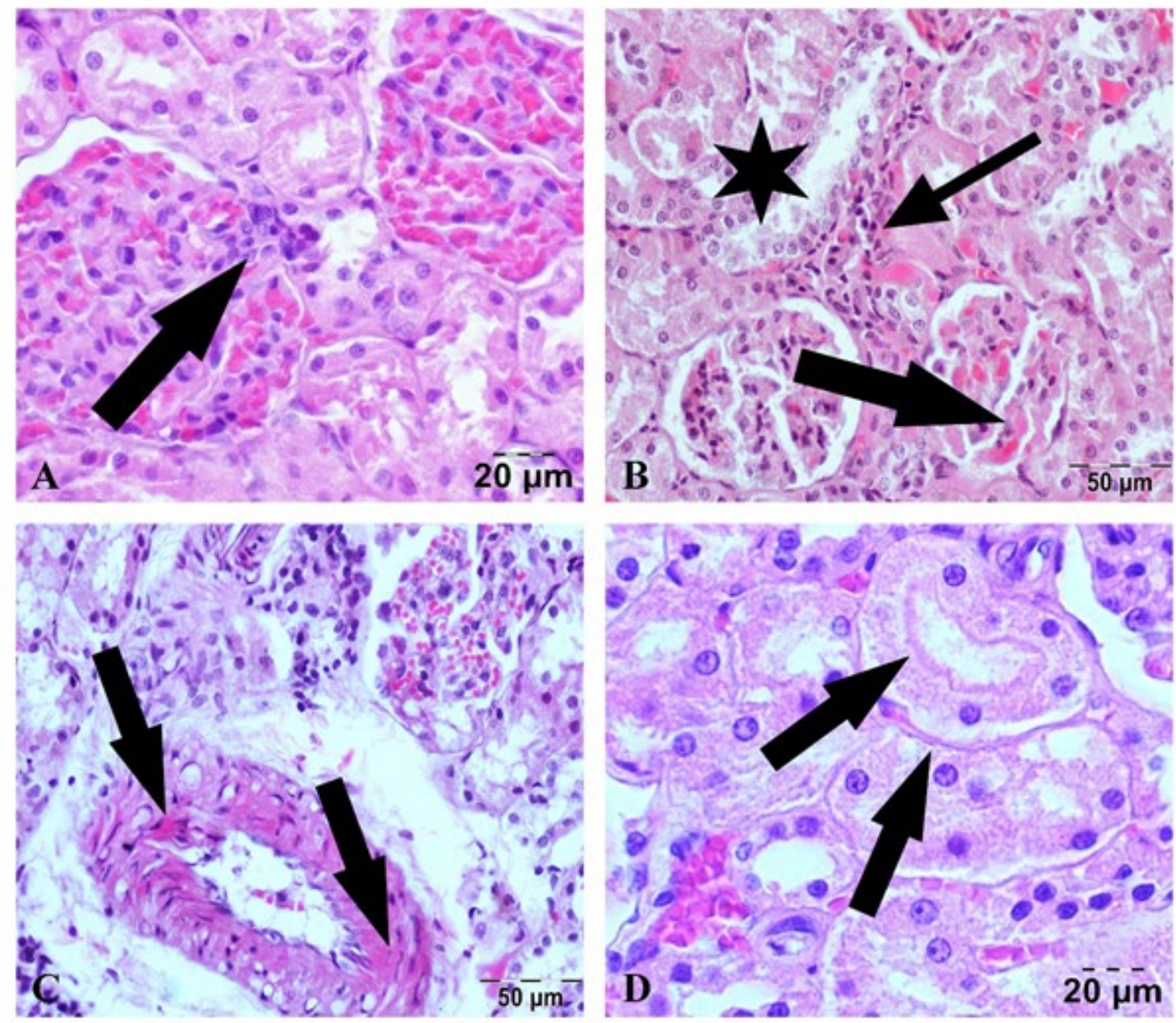

Şekil 1. Diyabetli ratlara ait böbrek dokusunun histopatolojik bulguları. A) Segmental proliferasyon (ok), HE. B) Glomeruler ve tubuler dejenerasyon (yıldız), glomeruler hiyalinizasyon (ok) ve peritubuler inflamasyon (ince ok), HE. C) Vasküler hyalinizasyon (oklar), HE. D) Tubul membranlarında kalınlaşma (oklar), HE.

hiperemi ile mesengial hücre proliferasyonları belirlendi. Glomerular vasküler kalınlaşma ile kimi alanlarda sklerozis ile karşılaşıldı. Ayrıca bowman kapsülünde genişlemeler gözlendi. Kimi glomeruler yapıların atrofik olduğu yer yer çevrelerinde hücresel infiltrasyonlar belirlendi. Periglomerular alanlarda fibrozis görüldü. Tubullerde ise, yaygın atrofi ile yer yer tubuler dilatasyonlar dikkati çekti. Kimi tubul lumenlerinde protein çökeltileri ile karşılaşıldı. Az sayıda alanda ise tubuler dejenerasyon ve nekrozis belirlendi. Tubul hücre sitoplazmalarında değişen şiddette vakuoller 

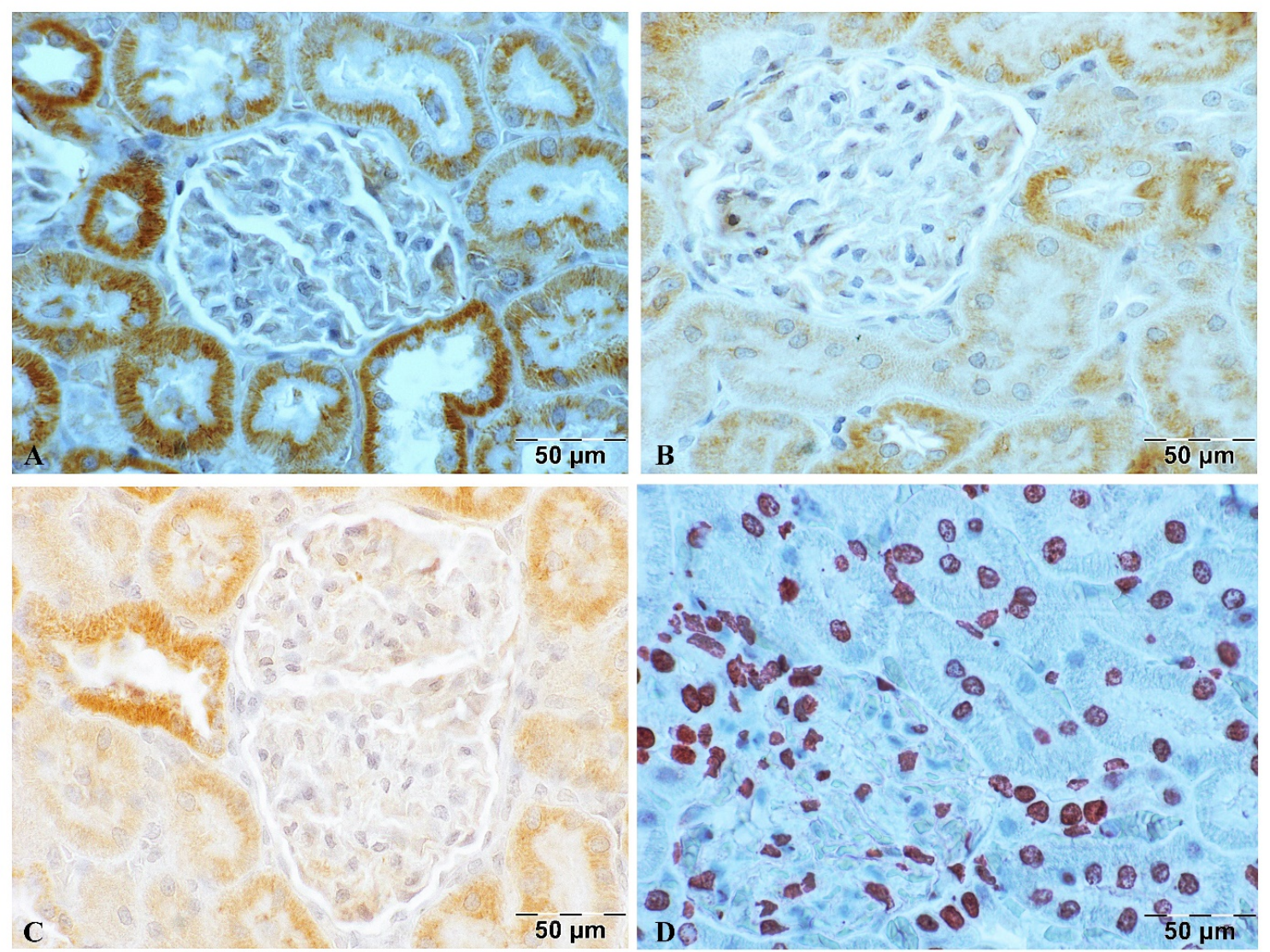

Şekil 2. Diyabetli ratlara ait böbrek dokusunun immunohistokimyasal bulguları. A) Kaspas-3 yönünden tubuller birlikte intersitisyum hücrelerinde pozitif reaksiyon, DAB. B) Kaspas-8 pozitif tubulus ve glomeruluslar, DAB. C) Kaspas-9 ile pozitif tubul epitel hücreleri, DAB. D) Tubullerde yoğun TUNEL reaksiyonu, AEC

gözlendi. Epitel hücrelerde apoptotik mikronükleus yapıları dikkati çekti. Gerek proksimal ve gerekse distal tubullerin çevresinde fokal fibrozis belirlendi. Yer yer bu alanlarda inflamasyon görüldü. Vasküler yapılarda hiperemi ile birlikte intimal fibrozis ve perivasküler inflamasyonlar tespit edildi.

\section{İmmunohistokimyasal bulgular}

Apoptozisin belirlenmesi amaciyla immmunohistokimyasal yapılan kaspas-3, Kaspas-8, Kaspas-9 ve TUNEL boyamalarında; DN oluşturulmuş böbreklerde belirgin ve yaygın immunopozitiflik dikkati çekti (Şekil 2).

Özellikle Kaspas-3 antikoruna karşı tubul epitel hücrelerinin yoğun pozitif reaksiyon gösterdiği belirlendi. Ayrıca kimi alanlarda intersitisyel dokuda az da olsa pozitif hücreler tespit edildi. Bazı vasküler endotelyal hücrelerde de benzer reaksiyonlar gözlemlendi. Glomeruler yapıda ise tek tük immunopozitif hücreler görüldü. Kaspas-8 ve kaspas-9 ile yapılan boyamalarda ise özellikle proksimal tubullerde pozitif reaksiyonun yaygın olduğu bununla birlikte distal tubullerde de immunopozitiflik gözlemlendi. Yer yer glomeruluslarda ve intersitisyel dokununda immunopozitif olduğu dikkati çekti. TUNEL boyamasında dokunun hemen hemen her alandaki tubul epitelerinin ve vasküler endotelin yaygın pozitif oldukları, bununla birlikte birçok glomerulusta ve interstisyel hücrelerde de immunopozitif reaksiyonların olduğu görüldü.

\section{Tartışma}

DM karbonhidrat metabolizması bozukluğu sonucu şekillenen ve hiperglisemi ile seyreden, kronik seyirli bir metabolizma bozukluğu olup birçok organ ve dokuda hasara neden olur. Diyabetin dokulardaki hasarı temelde yangısal, metabolik ve vasküler yapıdaki değişikliklere bağlı olarak oluşur (Estacio ve ark., 2012; Krolewski ve ark., 1996; Ozougwu ve ark., 2013). Özellikle hemodinamik sebepler nedeniyle hastalarda önemli oranda mortaliteye neden olan diyabetik nefropati olarak bilinen kronik böbrek yetersizliği şekillenir. Oldukça sinsi seyreden böbrek bozukluğu genellikle proteinüri dışında klinik semptom göstermeden ilerleyerek son dönem böbrek yetersizliği ile sonuçlanır (Dereli ve ark., 1999; Locatelli ve ark., 2004; Warram ve ark., 2010).

Diyabetik nefropatinin etiyopatogenezi henüz tam olarak açıklanmış olmasa da genel kanı 
hiperglisemi ve glikotoksisiteye bağlı dokularda artan sitokin, kemokin ve serbest radikaller gibi yangı tetikliyici faktörlerin artması ile oluşan mikrovasküler hasar sonucu şekillendiğidir (Krolewski ve ark., 1996; Warram ve ark., 1996). Serbest radikallerin artması ve sitokinlerin salgılanması damar endotelinde hasara neden olurken tromboz ve pıhtılaşmayı tetikler. Mikrovasküler yapıda meydana gelen bu hasar sonu böbrek dokusunda özellikle glomeruluslarda histopatolojik lezyonlar şekillenir (Sarnak ve ark., 2003; Tunçdemir ve ark., 2018; Wolf, 2004). Diyabetik nefropatide glomeruluslarda görülen bu patoloji hastalığın tanısında oldukça önemlidir (Mauer ve ark., 1990). Erken dönem glomeruler sklerozis en belirgin patolojik bulgu iken bowman kapsülündeki ve bazal membrandaki kalınlaşmalar ayrıca dikkati çeker. Bununla birlikte son dönem nefritis olarak kabul edilmesi nedeniyle böbrek biyopsisinde daha çok kronik bulgular ile karşılaşılır (Phillips ve Steadman, 2002; Tunçdemir ve Öztürk, 2008). Sıklıkla glomeruler hipertrofi ile birlikte tubulointersitsiyel dokudaki değişiklikler gözlemlenir. Glomeruler yapıdaki sklerozis noduler yapıya dönüşebilir. Glomeruler kapsülde kalınlaşmalar oldukça belirginleşir. Mezengial hücrelerdeki hipertrofi sonucu glomerulusların hacminde artış görülür (Fiorina ve ark., 2005; Kumar ve ark., 2004; Tunçdemir ve ark., 2018; Phillips ve Steadman, 2002). Kimi olgularda ise vasküler hyalinizasyonlarla karşılaşılabilir. Arteriosklerozis interstisyel arterlerde ve glomeruler kapillerde gözlemlenebilir. Tubulointerstisyel alanlarda ise belirgin fibrozis olgusu dikkati çeker. Tubuler bazal membranda kalınlaşmalar ile tubullerde dilatasyon ve atrofiler belirgindir. Bazı şiddetli ve kronik olgularda ise glomeruler ve tubuler yapıları kapsayan fokal nekroz alanları ile karşılaşılabilir (Kumar ve ark., 2004; Mauer ve ark., 1990; Phillips ve Steadman, 2002; Tunçdemir ve ark., 2018; Yaman ve Kömüroğlu, 2018). Hücrelerde artan glikojen hücre sitoplazmasında birikerek hücre hasarına ve sitoplazmik partiküllerin oluşmasına neden olur (Tunçdemir ve Öztürk, 2008). Yapılan bu çalışmadaki patomorfolojik bulgular literatür verileri ile benzer olduğu dikkati çekmektedir. Özellikle uzun dönem hiperglisemiye maruz bırakılan ratların glomeruler yapısındaki hasar belirgin şekilde gözlemlenmiştir. Glomeruler hipertrofi ve bowman kapsülündeki kalınlaşmaların vasküler yapıda meydana gelen hasarla ilişkili olabileceği düşünülmektedir. Kimi glomeruler vasküler yapıda hyalinizasyonun varlığı belirlenmiştir. Ayrıca tubuler yapıda görülen atrofiler ve yer yer dilatasyonlarda literatür verileri ile örtüşmektedir. Bazı tubul epitel hücrelerinde görülen vakuollerle birlikte apoptotik çekirdeklerin glikojen birikimine bağlı oluşan glikotoksikasyon sonucu şekillenmiş olabileceği kanısına varılmıştır. Çok olmasa da kimi tubullerde literatürde bahsedildiği gibi nekrozun şekillenmiş olduğu görüldü.

Kronik hiperglisemi ve glikoz toksikasyonuna maruz kalan dokulardaki kollajende, hücre içi proteinlerde ve DNA'da dönüşümsüz hasar oluşur. Diyabetik nefropatide oluşan vasküler iskemi ve artan serbest radikaller inflamasyona, apoptozise ve nekroze neden olur (Kumar ve ark., 2004; Ortiz ve ark., 1997; Tunçdemir ve ark., 2018; Zang ve ark., 1997). Farklı deneysel çalışmalarla oluşturulan böbrek hasarında kaspas yolaklarının rolünün olduğu bildirilmiştir. Tunçdemir ve ark. (2018) yaptıkları kapsamlı çalışmada, deneysel diyabetik ratların böbrek dokularında malondialdehit (MDA), ileri oksidasyon protein ürünlerinin (AOPP) ve protein karbonil (PC) gibi oksidasyon belirteçlerinin artış gösterdiğini belirlemişlerdir. Ayrıca diyabetik ratların böbrek dokularını immunohistokimyasal olarak, apoptotik, antiapoptotik, kaspas-3 ve TUNEL yöntemleri ile incelemiş ve apoptotizisi özellikte tubül hücrelerinde ve yer yer glomeruler yapılarda tespit etmiştir. Ortiz ve ark. (1997) hiperglisemik vakalarda antiapoptotik belirteç olan Bcl-2'nin azalmasına, buna karşılık apopotozisin göstergesi olarak kabul edilen Bax proteinin arttığını belirlemişlerdir. Kumar ve ark. (2004) hem tubul hemde interstisyel dokuda apoptozisin varlığını DN'li hastalara ait biyopsi örneklerinde tespit etmişlerdir. Yine Zang ve ark. (1997) deneysel oluşturulan DN'li ratların böbreklerinde tubul epitel hücrelerinde apoptozisin varlığını immunohistokimyasal olarak belirlemişlerdir. Her üç çalışmada da apoptozisin tubul epitel hücrelerinde özellikle proksimal ve distal tubullerde şekillendiği, ayrıca interstisyel hücrelerde yer yer apoptotik hücrelerin varlığını ortaya konmuştur. Yaman ve Kömüroğlu (2018) kaspas-3 yönünden özellikle proksimal tubul epitellerinde ve kimi glomeruler hücrelerde şiddetli pozitiflik tespit etmişlerdir. Tunçdemir ve Öztürk (2008) ise ratlarda deneysel oluşturdukları diyabetik nefropatide immnuhistokimyasal olarak distal tubullerle birlikte medullar tubullerde de apopotozisin yoğun olduğunu belirlemişlerdir. Ayrıca çalışmada glomeruler yapıda da az sayıdaki hücrede apoptozisin varlığını gözlemlemişlerdir. Bu çalışmada, immunohistokimyasal ve TUNEL yöntemi ile apoptozisin varlığı araştırıldı. Özellikle tubuler epitelde kaspas-3 reaksiyonun belirgin şekilde pozitif olduğu dikkati çekti. Buna karşılık kaspas-8 ve kaspas-9'un fokal alanlar halinde tubuler immunopozitif oldukları görüldü. Kaspas pozitifliğinin literatürle pararlel olarak distal ve medullar bölgelerde yoğunlaştığı dikkati çekmiştir. Kaspas-8 ve kaspas-9 pozitifliğinin tubuler yapılarda 
görülmesine karşılık kaspas-3'ün az sayıda glomerulusta da pozitif reaksiyon verdiği belirlenmiştir. Yine kaspas-3 antikoruna karşı intersitisyel dokudaki kimi hücrelerinde yer yer zayıf pozitif oldukları belirlenmiştir. Ayrıca yapılan TUNEL işaretlemede çekirdek pozitifliğinin kaspas boyamalarına oranla daha yoğun olduğu görülmüştür. Bu farklılığın apoptozis öncesi hücrelerde meydana gelen çekirdek kırılmalarının göstergesi olarak şekillendiği düşünülmektedir. TUNEL pozitifliği hemen hemen tubuler yapının tamamında görülürken glomeruler yapılarda da belirlenmiştir.

Sonuç olarak, diyabetik nefropatide şiddetli glomeruler hasar ile birlikte tubuler yapı ve interstisyel doku da etkilenmektedir. Vasküler değişiklikler ile birlikte fibrozis ve inflamasyon şekillenmektedir. Özellikle böbrek hasarında kaspas yolaklarının rolünün immunohistokimyasal olarak belirlenmiş olması ve TUNEL işaretlemelerinde çekirdek hasarının görülmesi böbreklerde ilerleyen ve geri dönüşümsüz hasarın varlığını göstermektedir.

\section{Kaynaklar}

Dereli D, Özbal EY, Akyurt M, Günal Z, 1999: Diyabetik nefropati etyopatogenezine güncel bir bakış. J SSK Tepecik Hosp Turkey, 9(2-3): 66-71.

Duran-Salgado MB, Rubio-Guerra AF, 2014: Diabetic nephropathy and inflammation. World I Diabetes, 5(3): 393-398.

Estacio RO, Jeffers BW, Gifford N, Schrier RW, 2000: Effect of blood pressure control on diabetic microvascular complications in patients with hypertension and type 2 diabetes. Diabetes Care, 23, 54-64.

Fioretto P, Steffes MW, Sutherland DER, Goetz FC, Mauer M, 1998: Reversal of lesions of diabetic nephropathy after pancreas transplantation. $N$ Engl J Med, 339: 69-75.

Fioretto P, Vestra MD, Saller A, Mauer M, 2000: Renal structure in type 2 diabetic patients with microalbuminuria. In: Mogensen CE (ed). The Kidney and Hypertension in Diabetes Mellitus. 5th ed. Norwell: Kluwer Academic Publishers, 225-236.

Fiorina P, Venturini M, Folli F, Losio C, Maffi P, et al. 2005: Natural history of kidney graft survival, hypertrophy, and vascular function in end-stage renal disease type 1 diabetic kidney-transplanted patients: beneficial impact of pancreas and successful islet cotransplantation. Diabetes Care, 28 (6): 1303-1310.

Friedman EA, 1996: Renal syndromes in diabetes. Endocrinol Metab Clin North Am, 25: 293-24.

Jones RK, Hamton D, O'Sullivan DJ, et al. 2013: Diabetes and renal disease. Clin Med, 13:460-464.

Krolewski AS, Warram JH, Freire MB, 1996: Epidemiology of late diabetic complications. A basis for the development and evaluation of preventive programs. Endocrinol Metab Clin North Am, 25:217242.

Kumar D, Zimpelmann J, Robertson S, Burns KD, 2004: Tubular and interstitial cell apoptosis in the streptozotocin-diabetic rat kidney. Nephron Exp Nephrol, 96: 77-88.

Locatelli F, Pozzoni P, Del Vecchio L, 2004: Renal replacement therapy in patients with diabetes and end-stage renal disease. J Am Soc Nephrol, 1: 25-29.

Mauer SM, Chavers BM, Steffes MW, 1990: Should there be expanded role for kidney biopsy in the management of patients with Type 1 diabetes? Am J Kidney Dis, 16: 96-100.

Nadir I, Topçu S, İçağasıoğlu S, Nilüfer Yıldırım N, 2003: Tip II Diabetes Mellitusta Nefropati Gelişiminde Risk Faktörleri. Van Tıp Dergisi: 10(3):65-68

Njolstad PR, Sagen JV, Bjorkhaug L, Odili S, Shehadeh N, Bakry D, Sarici SU, Alpay F, Molnes J, Molven A, Sovik O, Matschinsky FM, (2003). Permanent neonatal diabetes caused by glucokinase deficiency: inborn error of the glucose-insulin signaling pathway. Diabetes, 52(11): 2854-60.

Ortiz A, Ziyadeh FN, Neilson EG, 1997: Expression of apoptosis-regulatory genes in renal proximal tubular epithelial cells exposed to high ambient glucose and in diabetic kidneys. J Investig Med, 45: 50-56.

Ozougwu JC, Obimba KC, Belonwu CD, Unakalamba CB, (2013): The pathogenesis and pathophysiology of type 1 and type 2 diabetes mellitus. J Physiol Pathophysiol, 4(4): 46-57.

Parving HH, Ostorby R, Anderson PW, Hsuoh WA, 1996: Diabetic nephropathy. In: Brenner BM (ed). The Kidney. 5th ed. Philadelphia: WB Saunders Company, 1864-1892.

Phillips AO, Steadman R, 2002: Diabetic nephropathy: The central role of renal proximal tubular cells in tubulointerstitial injury. Histol Histopathol, 17: 247252.

Sarnak MJ, Levey AS, Schoolwerth AC, et al. 2003: American Heart Association Councils on Kidney in Cardiovascular Disease, High Blood Pressure Research, Clinical Cardiology, and Epidemiology and Prevention. Kidney disease as a risk factor for development of cardiovascular disease. Hypertension, 42: 1050-1065.

Strippoli GF, Di Paolo S, Cincione R, et al. 2003: Clinical and therapeutic aspects of diabetic nephropathy. J Nephrol, 16: 487-499.

Tunçdemir M, Ozturk M, 2008: The effects of ACE inhibitor and angiotensin receptor blocker on clusterin and apoptosis in the kidney tissue of streptozotocin-diabetic rats. J Mol Histol, 39: 605616.

Tunçdemir M, Mirzataş EB, Uzun H, 2018: Renoprotective potential of quercetin in experimental diabetic nephropathy: assesing antiapoptotic and antioxidant effects. Arch Clin Exp Med, 3(3):179-185.

Van Dijk C, Beri T, 2004: Pathogenesis of diabetic nephropathy. Rev Endocr Metab Disord, 5: 237-248.

Wang PH, Chahners TC, 1993: Metaanalysis of effects of intensive blood-glucose control on the late complications of type 1 diabetes. Lancet, 341: 13061309. 
Warram JH, Gearin G, Laffel L, Krolewski AS, 1996: Effect of duration of Type 1 diabetes on the prevelance of stages of diabetic nephropathy defined by urinary albumin/creatinine ratio. J Am Soc Nephrol, 7: 930937.

Warram JH, Scott LJ, Hana LS, et al. 2000: Progression of microalbuminuria to proteinuria in Type 1 diabetes: Non linear relationship with hyperglycemia. Diabetes, 49: 94-100.

Wolf G, 2004: New insights into the pathophysiology of diabetic nephropathy: from haemodynamics to molecular pathology. Eur J Clin Invest, 34: 785-796.
World Health Organization, 2016: Global Report on Diabetes. Geneva: World Health Organization.

Yaman Y, Kömüroğlu AU, 2018: Deneysel Diyabetik Ratlarda Ardıç (Juniperus communis L.) Yağının Nefropati Üzerine Etkileri. Harran Üniv Vet Fak Derg, 7(2): 192-199.

Zhang G, Khanna P, Chan LL, et al. 1997: Diabetes-induced apoptosis in rat kidney. Biochem Mol Med, 61:58-62.

*Yazışma Adresi: Nihat YUMUŞAK

Harran Üniversitesi, Veteriner Fakültesi, Eyyübiye Kampüsü, Şanlıurfa, Türkiye.

e-mail: nihatyumusak@harran.edu.tr 